\title{
AN INTER-COMPARISON OF THE SPATIAL AND TEMPORAL CHARACTERISTICS OF CO OVER HIGH FIRE REGIONS BASED ON MOPITT AND GFED
}

\author{
Chuyong Lin, Shuo Wang, Jason Blake Cohen* \\ School of Atmospheric Sciences, Sun Yat-Sen University, Zhuhai, China - linchuyong@ hotmail.com, \\ wangsh297@mail2.sysu.edu.cn, jasonbc@alum.mit.edu
}

Commission III, WG III/8

KEY WORDS: Carbon Monoxide, Biomass Burning, Fire, Carbon Emission, MOPITT, GFED

\begin{abstract}
:
The spatial and temporal distributions of Carbon Monoxide (CO) as measured by the Moderate Resolution Imaging spectroradiometer (MOPITT) instrument are analyzed in depth in this work. We specifically look at how these values, their statistics and their trends behave from 2000 to 2018 over regions defined as high fire regions, based on the carbon emissions product from the Global Fire Emission Database (GFED). Our results indicate that there are significant differences in the timing, duration, and magnitude of the fires as measured by MOPITT over different high fire regions. Our results are also different from past studies which have relied upon remotely sensed aerosol measurements, such as AOD. Over these high fire regions, we find that the fires contribute the vast majority of the CO loading, which always occurs over a short period of time, on order of weeks. Over 7 regions studied, we have found a statistically significant decreasing trend, albeit smaller than the measurement error. The correlation between the MOPITT and GFED approaches if found to be reliable over the regions where the two datasets overlap. We finally find evidence for possible long-range transport of $\mathrm{CO}$ from one fire region to another.
\end{abstract}

\section{INTRODUCTION}

There are few ways to directly measure or approximately constrain biomass burning fires from space. One approach is to directly measure the radiating emitted by a hot spot, such as via MODIS fire radiative power (FRP) measurements (Justice et al., 2002). However, this approach is not successful in cases where there is cloud cover over the fire (Giglio et al., 2003). A second is indirect, based on measuring the amount of burned area, such as an increase in blackness of the surface that suddenly changes with respect to the land cover, indicating a fire occurred (Giglio et al., 2013). But this approach both cannot describe the scale of the fire, and sometimes is also hampered by cloud cover of sufficient length that regrowth occurs, masking regions which burned (e.g. Kaufman et al. 2003; Lin et al. 2014). The third approach is to measure chemical species which are emitted directly by fires into the atmosphere, and which have a sufficiently long life time so as to survive in-situ to be measured (Prinn et al., 1987). Carbon monoxide (CO), which is produced by the incomplete combustion of carbon, and therefore is an important gas in the atmosphere playing a critical role with respect to atmospheric concentrations of ozone $\left(\mathrm{O}_{3}\right)$, carbon dioxide $\left(\mathrm{CO}_{2}\right)$, and the hydroxyl radical $(\mathrm{OH})$ (Seinfeld and Pandis, 1998), is one such species that can be used for this third approach.

Most approaches in the past to derive fire databases have been based on bottom up methods, such as The Global Fire Emission Database (GFED), The Fire INventory from NCAR (FINN) and EDGAR (van der Werf et al, 2017; Wiedinmyer, C., 2011; Olivier and Berdowski, 2001). These approaches have been demonstrated to offer a good first approximation, which can be

\footnotetext{
*Correspondence to Jason Cohen (jasonbc@alum.mit.edu)
}

further enhanced through top-down methods (i.e. Cohen and Wang, 2014).

Measuring $\mathrm{CO}$ from the space, a top down method, may allow for monitoring of the large-scale spatial and temporal distribution of fire sources to be tracked. One important aspect of top-down approaches is that they require validation, and therefore they pair well with ground station measurements, like in-situ NOAA ground station $\mathrm{CO}$ measurement, which provide much higher temporal resolution and more precise data which can be used to validate the measurement form the space (Deeter et al., 2014). Therefore, such a blending of top-down and bottom-up approaches have may prove to offer the best value, if they can be shown to be compatible with each other.

In this paper, we demonstrate the power of the top-down measurements from MOPITT to better understand and quantify the occurrence, magnitude, and changes in the biomass burning. We demonstrate findings in terms of spatial and temporal trends, as well as long-range transport and other scientific insights which are not as easily obtained from the more traditional bottom-up methods. We also demonstrate that there is a considerable amount of overlap and therefore hint at ways to move forward in terms of using both perspectives together.

\section{DATA AND METHODS}

\subsection{MOPITT CO Measurements}

In this work, the $\mathrm{CO}$ column measurements are retrieved from the Measurements of Pollution in the Troposphere (MOPITT) instrument on the EOS Terra satellite. We have used all of the daily retrieved version 8, level 3 daytime data from March 2000 
to 2018 (Deeter et al., 2017). We then use all of the cloudcleared, daytime data of high quality daily data available to form weekly average column values.

\subsection{Biomass Burning Emissions and Geography}

The Global Fire Emission Database (GFED) provides an estimate of the burned area and fire-based emissions of total carbon $\left(\mathrm{CO}_{2}+\mathrm{CO}+\mathrm{CH}_{4}\right)$ by using a combination of satellite measurements of burned area and measurements of vegetation productivity. We use the most recent version, GFED4s (van der Werf et al, 2017; http://www.globalfiredata.org). Specifically, we analyze the monthly biomass burning total Carbon emissions from 2000 to 2018 (which includes "beta level" data for 2017 and 2018). This is considered more reliable than the daily products, since there is no additional reliance on fire hotspot detections.

We present the climatology of the emissions (which we have determined correlates directly with the burned area) by plotting out the spatial distribution of the total sum of carbon emissions from 2000 to 2018 in Figure 1. We only include those points which first have a minimum total climatological emission magnitude greater than or equal to $190 \mathrm{~g} / \mathrm{m}^{2}$, which was chosen so that the total global emissions represented in our data is approximately $90 \%$ of the total annual emissions. Secondly, we require that every year's total emission value is greater than $0.5 \mathrm{~g} / \mathrm{m}^{2}$, which ensures that the fires occur regularly. This allows us to focus on those regions which are known to burn annually or multiple-times a year, and allows us to draw meaningful statistics given the errors in the MOPITT retrieved column values.

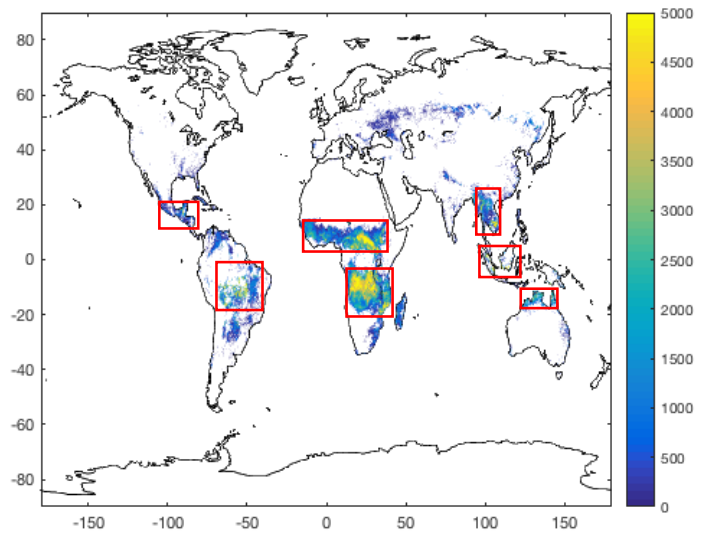

Figure 1. Global map of GFED total carbon emissions from 2000 through 2018 (carbon total emissions greater than 190 $\mathrm{g} / \mathrm{m}^{2}$ and every year containing a carbon emission greater than $0.5 \mathrm{~g} / \mathrm{m}^{2}$ ); Note the red boxes constrain the regions of interest used in this work.

As we can observe, the high fire regions based on GFED are concentrated in Mexico; the Amazon/Central Plains in South America; Western/Central Africa, Southern Africa (including Congo, Angola, Zambia and Tanzania); Northern Southeast Asia (including Myanmar, Thailand, Laos, Vietnam, and Cambodia); Southern Southeast Asia (including Sumatra, Malaysia, and Kalimantan); and Northern Australia. Based on these results, we constrained the study regions for $\mathrm{CO}$ columns to those regions within the red boxes in Figure 1. Respectively, the study regions are constrained between $105^{\circ} \mathrm{W}$ to $83^{\circ} \mathrm{W}$ and $12^{\circ} \mathrm{N}$ to $22^{\circ} \mathrm{N}$ (Mexico); $71^{\circ} \mathrm{W}$ to $45^{\circ} \mathrm{W}$ and $19^{\circ} \mathrm{S}$ to $1^{\circ} \mathrm{S}$ (South
America) $17^{\circ} \mathrm{W}$ to $39^{\circ} \mathrm{E}$ and $2^{\circ} \mathrm{N}$ to $13^{\circ} \mathrm{N}$ (Western/Central Africa); $11^{\circ} \mathrm{E}$ to $40^{\circ} \mathrm{E}$ and $20^{\circ} \mathrm{S}$ to $3^{\circ} \mathrm{S}$ (Southern Africa); $94^{\circ} \mathrm{E}$ to $109^{\circ} \mathrm{E}$ and $9^{\circ} \mathrm{N}$ to $27^{\circ} \mathrm{N}$ (Northern Southeast Asia); $98^{\circ} \mathrm{E}$ to $119^{\circ} \mathrm{E}$ and $4^{\circ} \mathrm{S}$ to $6^{\circ} \mathrm{N}$ (Southern Southeast Asia); and finally $120^{\circ} \mathrm{E}$ to $143^{\circ} \mathrm{E}$ and $22^{\circ} \mathrm{S}$ to $11^{\circ} \mathrm{S}$ (Northern Australia). Note that we also can observe there is high biomass burning carbon emission region over some high latitude areas, including Eastern Europe and Russia. However, the MOPITT CO measurements have a weak sensitivity over these high latitude areas, and therefore we did not include MOPITT measurements from these regions.

\section{RESULTS}

We observe that the time series of the weekly CO column averages over reach region vary greatly in space and time, as given in Figure 2. To account for the fact that extreme fires may occur within a small portion of each region, we also compute the time series of the maxima and the minima of the $\mathrm{CO}$ columns over each region at each weekly time step. Overall, each of these regions has a few common characteristics. First, over these high fire regions, the CO total column is relatively low throughout the entire year, but experiences a short and continuous period (from 4 to 12 weeks in length) with extremely high values during when the fires occur. Second, the weekly CO column loading has a relatively low average and high standard deviation over each region, as given in Table $\mathbf{1}$. Third, the ratio between the maximum value and the mean is much larger during these peak events, while the ratio between the minimum and the mean does not vary much over the time series.

The time series of each of these patterns are next compared with the time series of the biomass burning Carbon emissions from GFED over each of these regions. We are assured that there is a good representation from the GFED regions between the burned fraction and the Carbon emissions, since the burned area fraction is exclusively high over these regions. Therefore, if GFED carbon emissions and burned fraction are consistent, we expect a high correlation between these two different time series. Since CO is one of the major components of the Carbon emissions, we therefore endeavor to study the relationship between these two variables. Overall, we find a high level of correlation between the monthly GFED Carbon emissions time series and the weekly CO total column time series (renormalized to monthly), determining that the $\mathrm{R}^{2}$ coefficient or correlation ranges from 0.30 to 0.59 as given in Table $\mathbf{1}$.

Furthermore, we find that all of the high fire regions as defined by GFED show a statistically significant decreasing trend over the past 19 years, except for Southern Africa which did not pass the $\mathrm{p}$ test. Specifically, the weekly trend respectively is $2.55 \times 10^{14}$ molecules $/ \mathrm{cm}^{2}$ in Mexico, $-2.21 \times 10^{14}$ molecules $/ \mathrm{cm}^{2}$ in South America, $-1.04 \times 10^{14}$ molecules $/ \mathrm{cm}^{2}$ in Western/Central Africa, $-3.31 \times 10^{14}$ molecules $/ \mathrm{cm}^{2}$ in Northern Southeast Asia, $-2.61 \times 10^{14}$ molecules $/ \mathrm{cm}^{2}$ in Southern Southeast Asia and $-1.29 \times 10^{14}$ molecules $/ \mathrm{cm}^{2}$ in Northern Australia. These trends are computed using the total weekly values. Therefore, on an annualized basis, the trends are found to respectively be $-1.35 \times 10^{16}$ molecules $/ \mathrm{cm}^{2}$ in Mexico, $1.17 \times 10^{16}$ molecules $/ \mathrm{cm}^{2}$ in South America, $-0.55 \times 10^{16}$ molecules $/ \mathrm{cm}^{2}$ in Western/Central Africa, $-1.75 \times 10^{16}$ molecules $/ \mathrm{cm}^{2}$ in Northern Southeast Asia, $-1.38 \times 10^{16}$ molecules $/ \mathrm{cm}^{2}$ in Southern Southeast Asia and $-0.68 \times 10^{16}$ molecules $/ \mathrm{cm}^{2}$ in Northern Australia. Although these are statistically significant, they are still very small when compared 
with the mean total column values, and are actually smaller than the measurement error in the $\mathrm{CO}$ total column values themselves. Therefore, this finding provides deep insight and warrants further on-the-ground evaluations to better understand if these changes are truly occurring in these respective regions.
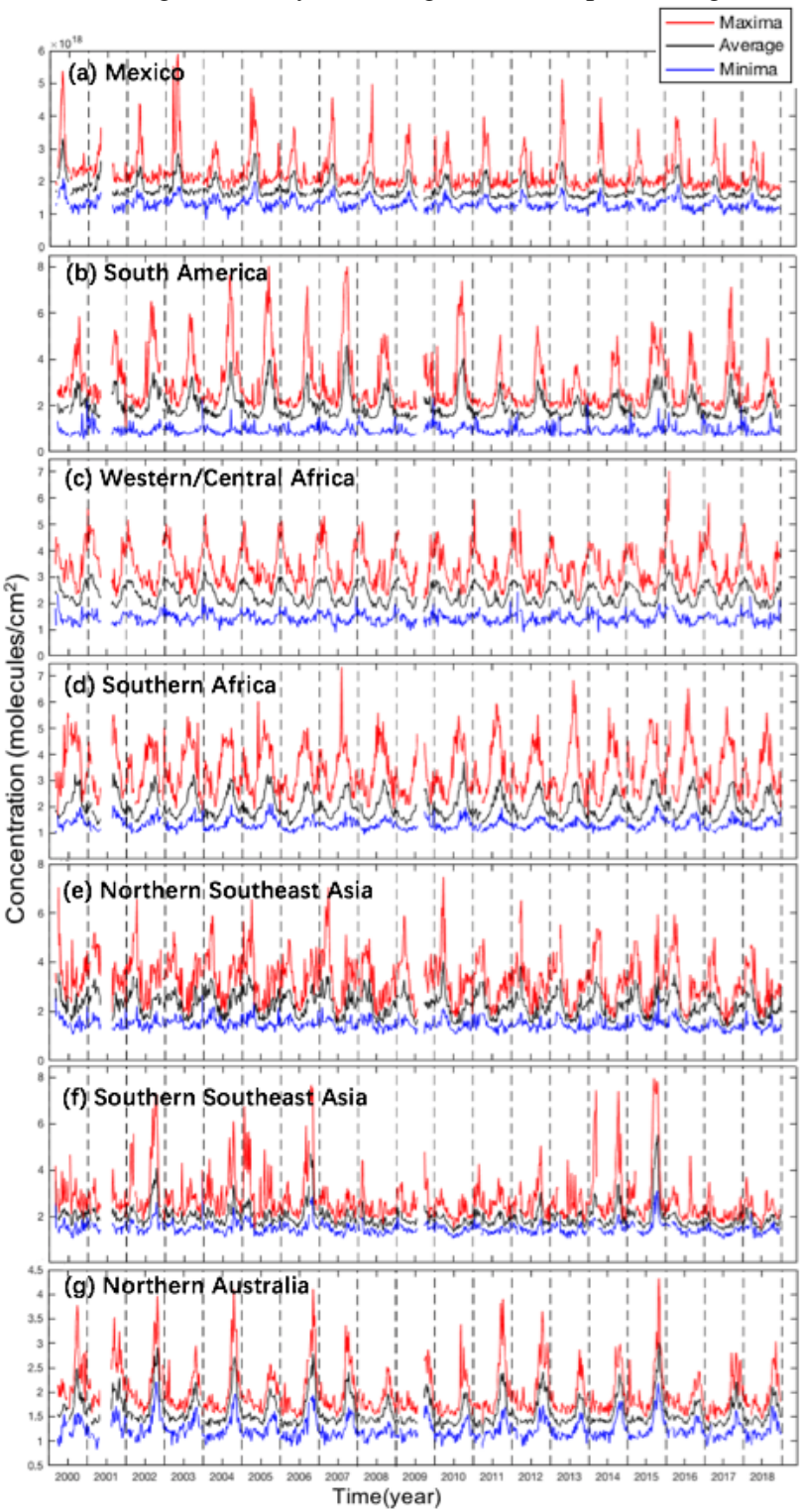

Figure 2. Time series of MOPITT CO total column the maxima (red curves), average (black curves), and minima (blue curves) over the interest regions.

Fires with different magnitudes and different durations occur in different high fire region of the world. Respectively, the fire occurs in late April to May (lasting for 4 to 6 weeks) over Mexico, where the $\mathrm{CO}$ concentration has an average of $1.76 \times 10^{18}$ molecules $/ \mathrm{cm}^{2}$ and a standard deviation of $2.73 \times 10^{17}$ molecules $/ \mathrm{cm}^{2}$. Peaks of the maxima over region in the year 2004 are much high than the other years, with the global maxima being $5.88 \times 10^{18}$ molecules $/ \mathrm{cm}^{2}$.

Fires occur in August to September (lasting for 5 to 7 weeks) over South America, where the CO concentration has an average of $1.95 \times 10^{18}$ molecules $/ \mathrm{cm}^{2}$ and a standard deviation of $5.31 \times 10^{17}$ molecules $/ \mathrm{cm}^{2}$. South America is the region of the world with the largest standard deviation in the CO column loading. There are abnormally high peaks that occur in 2004,
2005, 2006, 2007, 2010, and 2017, which do not comprehensively match with any well-known simple dynamical system such as el-Niño. Overall, the respective maxima also have a strong amount of variance, ranging from $3.79 \times 10^{18}$ to $8.04 \times 10^{18}$ molecules $/ \mathrm{cm}^{2}$.

\begin{tabular}{|c|c|c|c|c|}
\hline \multirow[t]{2}{*}{ Regions } & Average & $\begin{array}{l}\text { Standard } \\
\text { deviation }\end{array}$ & $\begin{array}{c}\text { Trend } \\
\text { (weekly) }\end{array}$ & \multirow{2}{*}{$\begin{array}{c}\mathrm{R}^{2} \text { with } \\
\text { GFED C } \\
\text { emissions }\end{array}$} \\
\hline & \multicolumn{3}{|c|}{ unit: $\times 10^{18}$ molecules $/ \mathrm{m}^{2}$} & \\
\hline Mexico & 1.76 & 0.03 & -2.55 & 0.59 \\
\hline $\begin{array}{c}\text { South } \\
\text { America }\end{array}$ & 1.95 & 0.53 & -2.21 & 0.35 \\
\hline $\begin{array}{c}\text { Western/ } \\
\text { Central } \\
\text { Africa }\end{array}$ & 2.32 & 0.35 & -1.04 & 0.52 \\
\hline $\begin{array}{l}\text { Southern } \\
\text { Africa }\end{array}$ & 2.02 & 0.45 & $\mathrm{NaN}$ & 0.30 \\
\hline $\begin{array}{c}\text { Northern } \\
\text { Southeast } \\
\text { Asia }\end{array}$ & 2.28 & 0.48 & -3.31 & 0.50 \\
\hline $\begin{array}{c}\text { Southern } \\
\text { Southeast } \\
\text { Asia }\end{array}$ & 1.97 & 0.45 & -2.61 & 0.36 \\
\hline $\begin{array}{l}\text { Northern } \\
\text { Australia }\end{array}$ & 1.60 & 0.30 & -1.29 & 0.45 \\
\hline
\end{tabular}

Table 1. Statistics of MOPITT CO total column measurements over the regions of interest, and coefficient of correlation $\left(\mathrm{R}^{2}\right)$ between MOPITT CO and GFED C emissions

In Africa, there are two distinctly separate high fire regions, located in the center of Africa spreading to the West, and in Southern Africa. Even though they are close to each other geographically, the burning times are different, which is consistent with the fact that one is in the Northern Hemisphere while the other is in the Southern Hemisphere. On one hand, high fires over Western/Central Africa occur from December to March, while on the other hand, high fires over Southern Africa occur from late June to early October (lasting 3 months on average and even longer in some years). Southern Africa is the region of the world which has the longest duration of the fire season. Additionally, when high fire events occur over Africa in one of the high fire regions, it leads to a second, more minor peak in the other region at the same time. The peaks of the average value over region over each year are at a similar magnitude over the past 19 years in these two regions. This lends evidence to the strong possibility that there is downwind transport of $\mathrm{CO}$ from fire emissions occurring in one region, being transported to the other region respectively.

Over Northern Southeast Asia, the high fire season occurs regularly from February to April (with the maximum always found sometime in March). Fires in Southern Southeast Asia however, show a huge variance inter-annually. In this region, there is no regular time series, with a few years exhibiting extreme fires, such as in 2002, 2004, 2005, 2006, 2014, 2015, while in other years the fire events are relatively small or even impossible to detect over portions of the geographical area, with such low years occurring in 2007, 2013, 2017 and 2018. The maximum varies vastly, with a high and low value of $7.47 \times 10^{18}$ and $1.43 \times 10^{18}$ molecules $/ \mathrm{cm}^{2}$ respectively. Furthermore, in a few years, it is even possible to detect multiple fire seasons. Another interesting thing is that the timing of the fires with the most extreme peaks are found in September to October (as 
compared to previous findings based on aerosols which tend to leave out October). Additionally, the secondary peaks (when they are found) occur in February to March. Again, there is a possible connection with transport from the Northern region to the Southern one, although this has not been previously discussed in the literature.

Fires occur in late September to October over Australia and have an average $\mathrm{CO}$ loading of $1.60 \times 10^{18}$ molecules $/ \mathrm{cm}^{2}$ with a standard deviation of $3.0 \times 10^{17}$ molecules $/ \mathrm{cm}^{2}$. The burning timing is similar to that found over Southern Southeast Asia. This again points to the possibility of transport between the regions.

\section{DISCUSSION AND CONCLUSION}

We have analyzed the weekly MOPITT measured CO total column over the high fire regions, as constrained by the GFED biomass burning carbon emission dataset, from 2000 through 2018. Over most the high fire regions, we have observed a decreasing trend, varying from $-1.04 \times 10^{14}$ molecules $/ \mathrm{cm}^{2}$ to $2.55 \times 10^{14}$ molecules $/ \mathrm{cm}^{2}$, all of which are an order of magnitude of 4 smaller than the average conditions over the respective areas. We also have discovered that the burning time over each high fire region are not as found by previous studies which have relied mostly on aerosol and AOD measurements. Our findings respectively are late April to May over Mexico, August to September over the South America, December to March over the Central Africa, late June to early October over the Southern Africa, February to April over Northern Southeast Asia, September to October in Southern Southeast Asia, and late September to October over Australia. The maxima over the Southern Southeast Asia region had the highest magnitude among all of the high fire regions, with a value of $7.98 \times 10^{18}$ molecules $/ \mathrm{cm}^{2}$. The average value over the Western/Central African fire region had the highest value over all of the regions, with a value of $2.32 \times 10^{18}$ molecules $/ \mathrm{cm}^{2}$. On top of this, the highest standard deviation was found in the Southern African high fire region with a value of $5.3 \times 10^{17}$ molecules $/ \mathrm{cm}^{2}$. Last, but not least, we have found some possibilities of transport of fires from one fire region to another, although further work is required to support this point.

Of the uncertainty in this work, we chose to use the box to constrained the interest region instead of the exact high carbon emission region on the surface. Furthermore, we focus on the $\mathrm{CO}$ total column in this work, which is the integral of the $\mathrm{CO}$ loading throughout the whole atmosphere. CO emissions originate from the surface in the fire region, but do loft at height. However, the plume also spreads in the horizontal faster at higher levels. Therefore, surface emissions of carbon emissions do not provide a full amount of insight into what is occurring above the surface. Even so, the box which we use to enclose each high fire region can capture the full extent of the $\mathrm{CO}$ emissions and spread better, but also may cover some adjacent regions where there is no fire occurring. This will cause the uncertainty, and is the major reason why we present and analyze not only the time series of the average value over an interest region, but also the time series of the maxima and minima value over our various regions of interest.

\section{ACKNOWLEDGEMENTS}

We would like to acknowledge the PIs of the MOPITT instrument for providing the remote sensing measurements, and the GFED team for their emissions products. The work was supported by the Chinese National Young Thousand Talents Program (Project 74110-41180002), the Chinese National Natural Science Foundation (Project 74110-41030028), and the Guangdong Provincial Young Talent Support Fund (Project 74110-42150003).

\section{REFERENCES}

Cohen, J.B., Wang, C., 2014. Estimating global black carbon emissions using a top-down Kalman Filter approach. $J$. Geophys. Res. Atmos., 119. dx.doi.org/10.1002/2013JD019912.

Deeter, M.N., Martínez-Alonso, S., Edwards, D.P., Emmons, L.K., Gille, J.C., Worden, H.M., Sweeney, C., Pittman, J.V., Daube, B.C., and Wofsy, S.C., 2014. The MOPITT Version 6 product: algorithm enhancements and validation, Atmos. Meas. Tech., 7, 3623-3632, doi.org/10.5194/amt-7-3623-2014.

Deeter, M.N., Edwards, D.P., Francis, G.L., Gille, J.C., Martínez-Alonso, S., Worden, H.M., and Sweeney, C., 2017, A climate-scale satellite record for carbon monoxide: the MOPITT Version 7 product. Atmos. Meas. Tech., 10, 2533-2555, doi.org/10.5194/amt-10-2533-2017.

Giglio, L., Descloitres, J., Justice, C.O., Kaufman, Y., 2003. An enhanced contextual fire detection algorithm for MODIS, Remote Sens. Environ. 87 273-82

Giglio, L., Randerson, J.T., and van der Werf, G.R., 2013, Analysis of daily, monthly, and annual burned area using the fourth-generation global fire emissions database (GFED4), $J$. Geophys. Res. Biogeo., 118, 317-328, doi.org/10.1002/jgrg.20042, 2013.

Justice, C.O., Giglio, L., Korontzi, S., Owens, J., Morisette, J. T., Roy, D., Descloitres, J., Alleaume, S., Petitcolin, F., Kaufman, Y., 2002, The MODIS fire products. Remote Sensing of Environment. 83. 244-262.

Kaufman, Y.J., Ichoku, C., Giglio, L., Korontzi, S., Chu, D. A., Hao, W.M., and Justice, C.O., 2003. Fire and smoke observed from the Earth Observing System MODIS instrument-products, validation, and operational use. Int. J. Remote Sens., 24, 17651781. doi.org/10.1080/01431160210144741

Lin, N.H., Sayer, A.M., Wang, S.H., Loftus, A.M., Hsiao, T.C., Sheu, G.R., and Chantara, S., 2014. Interactions between biomass- burning aerosols and clouds over Southeast Asia: Current status, challenges, and perspectives, Environ. Pollut., 195, 292-307.

Olivier, J., Berdowski, J.J.M., 2001. Global emissions sources and sinks, The Climate System, edited by: Berdowski, J., Guicherit, R., and Heij, B. J., A. A. Balkema Publishers/Swets \& Zeitlinger Publishers, Lisse, the Netherlands, 33-78.

Prinn, R., Cunnold, D., Rasmussen, R., Simmonds, P., Alyea, F., Crawford, A., Fraser, P., Rosen, R., 1987. Atmospheric Trends in Methylchloroform and the Global Average for the Hydroxyl Radical. Science (New York, N.Y.). 238. 945-50. doi.org/10.1126/science.238.4829.945.

Seinfeld, J., Pandis, S., 1998. Atmospheric Chemistry and Physics: From Air Pollution to Climate Change. Physics Today, 51, 10, 88, doi.org/10.1063/1.882420. 
van der Werf, G.R., Randerson J.T., Giglio, L., van Leeuwen T.T., Chen Y., Rogers B.M., Mu M., van Marle M.J.E., Morton D.C., 2017. Global fire emissions estimates during 1997-2016. Earth System Science Data 9.2:697-720.

Wiedinmyer, C., Akagi, S.K., Yokelson, R.J., Emmons, L.K., Al-Saadi, J.A., Orlando, J.J., and Soja, A.J. 2011: The Fire INventory from NCAR (FINN): a high resolution global model to estimate the emissions from open burning, Geosci. Model Dev., 4, 625-641, doi.org/10.5194/gmd-4-625-2011.

Revised August 2019 